\title{
Diagnosis and management of pertussis
}

\author{
Alberto E. Tozzi, Lucia Pastore Celentano, Marta Luisa Ciofi degli Atti, Stefania Salmaso
}

Abstract

PERTUSSIS IS INCREASING IN FREQUENCY among children too young to be vaccinated and among adolescents and adults. This increase is due mainly to waning immunity among vaccinated individuals, who become susceptible during adolescence and adulthood and maintain the circulation of Bordetella pertussis. Infants are at highest risk of severe illness requiring hospital admission, complications and death. The clinical presentation in adolescents, adults and vaccinated individuals may be atypical, with paroxysmal cough of short duration or simply a persistent cough. Culture and polymerase chain reaction may be used to identify $B$. pertussis infection, but their sensitivity is high only in the early phase of the disease. Serologic tests are not standardized for the diagnosis of pertussis, and their clinical application is limited. Erythromycin is still considered in some countries to be the "gold standard" for therapy and prophylaxis; however, azithromycin and clarithromycin seem equally efficacious and are associated with fewer side effects.

CMAJ 2005;172(4):509-15

$\mathrm{T}$ he increase worldwide in vaccination coverage against pertussis has substantially reduced the morbidity and mortality associated with this disease. However, because of variability in age-specific vaccine coverage rates and waning immunity, the epidemiologic pattern of pertussis in developed countries has radically changed. Managing pertussis in a setting with high rates of vaccination uptake requires knowledge of the clinical picture of pertussis according to the vaccination status and age of the patient, the most sensitive and timely laboratory tests for diagnosis, and the safest and most efficacious methods of treatment and prophylaxis. In this article we review recent findings and issues in the diagnosis, treatment and prophylaxis of pertussis. (An outline of our strategy for the literature search is available in Appendix 1.)

\section{Epidemiology and pathogenesis}

In the 1990s Bordetella pertussis caused an estimated 20 to 40 million cases of pertussis worldwide and 200000 to 400000 deaths each year. ${ }^{1}$ Although improved vaccination coverage has decreased the incidence of pertussis dramatically over the last decade, many developed countries have recently experienced a resurgence of the disease among infants too young to be vaccinated and among adolescents and adults. ${ }^{2-6}$ Outbreaks have been reported even in popula- tions with high vaccination coverage, primarily because of waning immunity, which results in a large number of susceptible adolescents and adults. ${ }^{7}$ Indeed, neither natural infection nor primary immunization induces permanent immunity. ${ }^{8}$ Because of its variable presentation among patients with different degrees of susceptibility, pertussis is likely largely underdiagnosed among young infants and among adults unless an outbreak occurs.

$B$. pertussis is transmitted person to person by close contact with aerosolized droplets. The incubation period may vary between 6 and 21 days but is typically $6-10$ days. Bacteria invade and damage the epithelium of the airway and the alveoli through the combined action of several virulence factors that interfere with normal ciliary movement (Fig. 1), namely fimbriae, pertactin, pertussis toxin, filamentous hemagglutinin, adenylate cyclase, tracheal cytotoxin, dermonecrotic toxin, lipopolysaccharide, tracheal colonization factor, serum resistance factor and type III secretion. ${ }^{9}$ Symptoms of pertussis may persist long after clearance of the infecting organism has occurred..$^{10}$

\section{Clinical presentation}

After the incubation period, pertussis begins with a catarrhal phase. This phase lasts 1-2 weeks, during which patients are most contagious, and it is clinically indistinguishable from a mild upper respiratory tract infection. As the catarrhal stage progresses, the cough increases in frequency and severity. The subsequent paroxysmal phase, which lasts 3-6 weeks, is characterized by spells of coughing with the characteristic whoop, vomiting, cyanosis and apnea. The symptoms gradually decrease in severity during the convalescent phase, which can last up to several months (Table 1).

The clinical course may be influenced by various factors, including age, sex and immunization status of the patient (Table 2, Table 3). Observations made on the determinants of the clinical presentation of 788 laboratory-confirmed cases of pertussis in children during a trial in Italy of acellular pertussis vaccines found that the clinical course of pertussis was independent of age and sex until the age of 3; after this age, the duration of spasmodic cough was 7 days longer among girls than among boys and decreased with age, and the duration of cough increased..$^{11}$ Many children under 6 months of age do not develop paroxysmal cough or the characteristic inspiratory whoop. Recurrent episodes of apnea, cyanosis and bradycardia can dominate the clinical 
picture in infants, and a prolonged and complicated course is often observed. ${ }^{13,14}$ Although adolescents and adults usually experience the 3 typical stages of pertussis, some may have only a protracted cough.,15 Smoking or asthma may increase the duration of paroxysmal cough and the number of nights with disturbed sleep..$^{15}$ Pertussis is less severe in vaccinated individuals. ${ }^{11,12,16}$ One study involving vaccinated people 5-30 years of age showed that the 3 typical stages of pertussis were absent, the clinical course was characterized by cough lasting a median of 3 weeks, and only $6 \%$ of the patients with pertussis had the classic whoop. ${ }^{16}$

\section{Complications}

The most frequent complication observed in children is pneumonia, which occurs in $6 \%$ of cases. ${ }^{17}$ Other complications include sinusitis, otitis media, viral and bacterial superinfections, nutritional deficiencies resulting from repeated vomiting and neurologic complications, which are due mostly to hypoxia during coughing spells and apnea., ${ }^{8,17}$ In 1990 it was estimated that 50000 children worldwide experienced long-term neurologic complications of pertussis, ${ }^{18}$ and in the late 1990s it was reported that 0.9 per 100000 pertussis cases were complicated by encephalopa- thy. ${ }^{19}$ The risk of complications is higher among infants and adults than among older children and adolescents. In a prospective case series in Germany, the rate of complications among infants less than 6 months of age was $24 \%$, as compared with $5 \%$ among older children. ${ }^{17}$ In the first 2 months of life, pneumonia, seizures and encephalopathy have been reported in $25 \%, 3 \%$ and $1 \%$ of cases, respectively.$^{20}$ Cardiac arrhythmias and episodes of intractable hypoglycemia have also been reported. ${ }^{14}$ After childhood, the risk of complications increases with age. ${ }^{15,17}$ Pneumonia has been observed in $2 \%$ of patients less than 30 years of age, as compared with $5 \%-9 \%$ of older patients. Syncope, urinary incontinence, back pain, rib fracture and hernia have been also described. ${ }^{8,15}$

Severe paroxysm, post-tussive cyanosis, whooping, posttussive vomiting, apnea, pneumonia and seizures are the most frequent reasons patients are admitted to hospital, regardless of age. ${ }^{21-23}$ Infants, especially those who have not been vaccinated or have been incompletely vaccinated, are the most likely to require hospital care. ${ }^{6,21-30}$ Birth before 37 weeks' gestation and low birth weight have been inconsistently indicated as independent risk factors for hospital admission. ${ }^{21,23}$

Death from pertussis is inversely related to age, with almost $90 \%$ of reported deaths occurring in unvaccinated

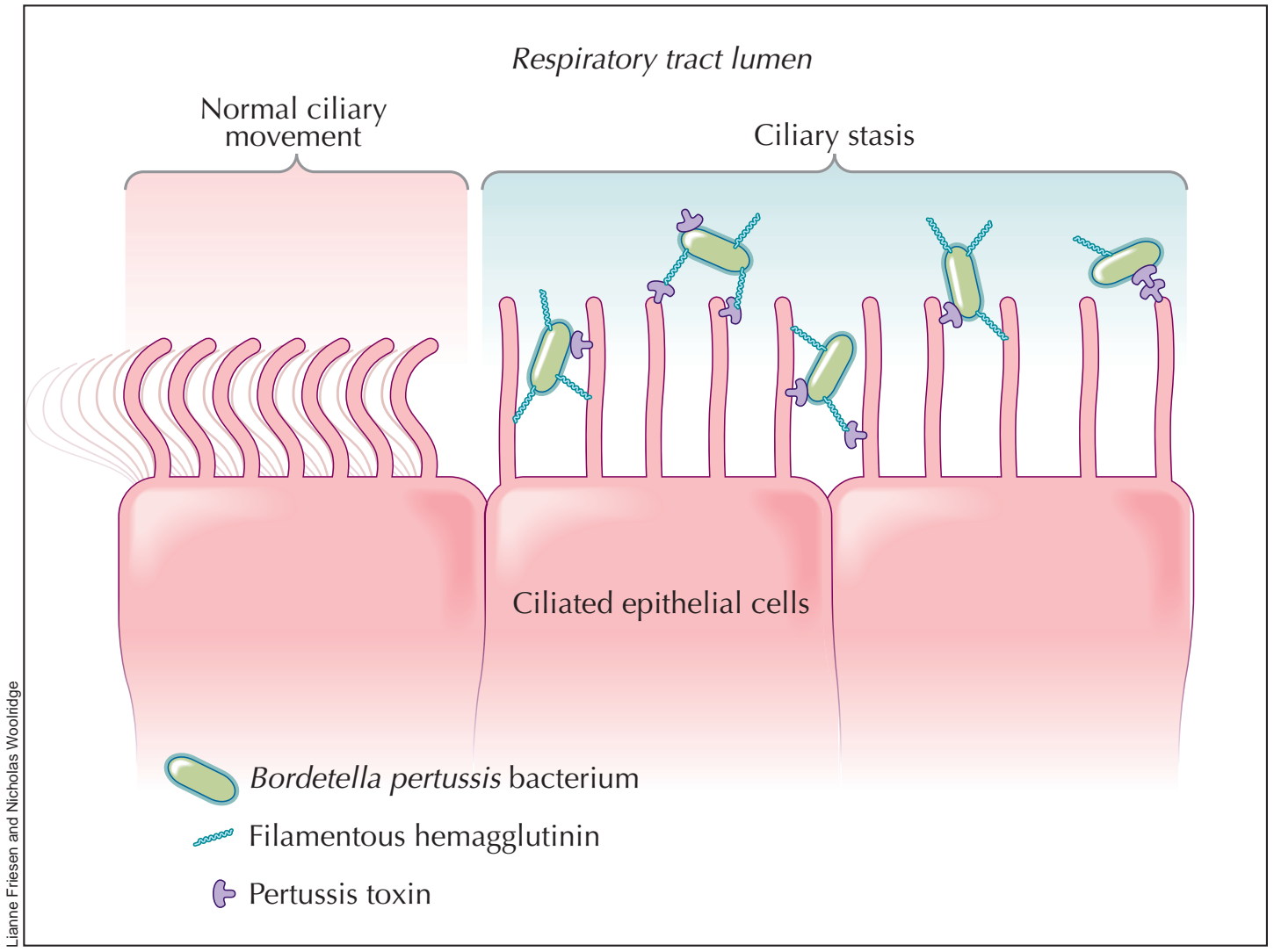

Fig. 1: Synergy between pertussis toxin and filamentous hemagglutinin in binding to ciliated respiratory epithelial cells. Bordetella pertussis attach strongly to the ciliated cells with the combined action of other adhesins (e.g., fimbriae and pertactin). Pertussis toxin has the ability to enter the bloodstream and plays an important role in the induction of clinical immunity. 
infants less than 1 year old, who have a case-fatality rate of $0.6 \% .^{20,31,32}$ High levels of leukocytosis and lymphocytosis may predict a fatal outcome in children admitted to hospital. ${ }^{32-35}$ An association between pertussis and sudden unexpected death in infants has been observed. ${ }^{36}$ Therefore, pertussis should be ruled out in cases of sudden infant death syndrome.

\section{Diagnosis}

A mild increase in the leukocyte count and marked lymphocytosis are classic markers of pertussis and have been shown to be useful indicators of the disease if observed with typical symptoms or positive microbiological assay results. ${ }^{37}$ Traditional laboratory methods for diagnosis include identification of $B$. pertussis through culture of nasopharyngeal secretions and serologic testing for evidence of seroconversion of specific antibodies in the convalescent phase of the disease compared with the acute phase. High rates of vaccination coverage, the occurrence of cases with mild symptoms, recurrence of natural exposure and the increased age at which pertussis develops influence the sensitivity and specificity of the laboratory methods (Table 4), and no single assay is considered to be the "gold standard" in common practice.

For culture, nasopharyngeal secretions are collected through swabbing or aspiration. Culture takes several days to be completed and includes an enrichment step and the use of selective media in order to prevent growth of competing organisms of the upper respiratory tract. ${ }^{9} \mathrm{Al}-$ though the positive predictive value is $100 \%$, the sensitivity of culture is highest in the early stage of infection, before the natural clearance of bacteria, in severe cases, in unvaccinated patients and in infants (Table 1). ${ }^{46-48}$ The likelihood of a positive result may be negatively affected by antibiotic treatment.
Polymerase chain reaction (PCR) methods enhance the probability of identification of $B$. pertussis, since positive results may be obtained even when the organism is no longer culturable. In a recent study in France involving 217 adults with persistent cough, 70 had laboratory-confirmed pertussis (confirmed by culture, PCR or serologic testing); of these cases, only 1 was confirmed by means of culture, as compared with 36 by PCR. ${ }^{40}$ PCR assays require the availability of adequate specimens as well as particular laboratory experience, since the risk of false-positive results is high. ${ }^{49}$ Sensitivity and specificity of PCR depend on the primers used, and various combined techniques have been reported to enhance the performance of this method..$^{50,51}$ However, the sensitivity of PCR decreases with the duration of symptoms, since the method is based on the detection of the microorganism.

Serologic testing is based on the identification of a significant variation in IgG or IgA titres against the most rel-

Table 2: Observed influence of factors on duration of cough and spasmodic cough in children with pertussis ${ }^{11}$

\begin{tabular}{lcc}
\hline Factor & $\begin{array}{c}\text { Effect on duration } \\
\text { of cough }\end{array}$ & $\begin{array}{c}\text { Effect on duration } \\
\text { of spasmodic } \\
\text { cough }\end{array}$ \\
\hline Immunized with an acellular & $\downarrow$ & $\downarrow$ \\
pertussis vaccine & $\uparrow$ & $\uparrow$ \\
Culture positive pertussis & $\uparrow$ & $\uparrow$ \\
Received antibiotic treatment* & $\leftrightarrow$ & $\leftrightarrow \dagger$ \\
Female sex & $\uparrow$ & $\downarrow \neq$ \\
Age & $\leftrightarrow$ & $\leftrightarrow$ \\
Background incidence & $\leftrightarrow$ \\
\hline
\end{tabular}

Note: $\downarrow=$ decrease, $\uparrow=$ increase, $\leftrightarrow=$ no effect.

*Antibiotic use thought to be a marker of disease severity.

†Female sex was associated with a longer duration of spasmodic cough only in children over 33 months of age.

‡Age was inversely related to duration of spasmodic cough only in children over 33 months of age.

\begin{tabular}{lccc}
\hline $\begin{array}{l}\text { Table 1: Typical course of pertussis - evolution of symptoms, relative sensitivity of } \\
\text { diagnostic methods and effect of antibiotic therapy, by phase of pertussis }\end{array}$ \\
$\begin{array}{lccc}\text { Catarrhal phase } \\
(1-2 \mathrm{wk})\end{array}$ & $\begin{array}{c}\text { Paroxismal phase } \\
(3-6 \mathrm{wk})\end{array}$ & $\begin{array}{c}\text { Convalescent phase } \\
(>6 \mathrm{wk})\end{array}$ \\
Variable & & & ++ \\
Symptom & ++ & +++ & $-/+$ \\
Cough & $-/+$ & +++ & $-/+$ \\
Paroxysmal cough & - & +++ & $-/+$ \\
Whooping cough & - & +++ & - \\
Vomiting & - & +++ & - \\
Cyanosis & - & +++ & - \\
Apnea & & & - \\
Test sensitivity & ++ & $-/+$ & ++ \\
Culture & ++ & ++ & - \\
PCR & $-/+$ & ++ & \\
Serology & & $-/+$ & \\
Effect of antibiotic therapy & ++ & & \\
Symptoms alleviated & & &
\end{tabular}

Note: + present, - absent, -/+ equivocal. 
evant virulence factors of $B$. pertussis between the acute and the convalescent phases of the disease. The antigens most often targeted by such testing are pertussis toxin, filamentous hemagglutinin and pertactin. However, the ability to show seroconversion may be affected by the previous immunological priming of the patient (owing to vaccination or previous infection) and by when serum samples are collected. If the acute sample is taken after the specific humoral response has already been elicited, seroconversion may be difficult to detect. In one study, although a vigorous antibody response to adenylate cyclase toxin was elicited by natural infection in previously unvaccinated patients, the response was very limited in patients who had been vaccinated. ${ }^{52}$ Therefore, diagnosis by means of serologic testing may be difficult in vaccinated or adult patients.

Identification of a cutoff value for detecting acute infection from a single serum sample has been attempted by studying the kinetics of the humoral response. ${ }^{53-55}$ Only humoral responses to pertussis toxin have been shown to be consistent among vaccinated and unvaccinated patients. Responses to filamentous hemagglutinin have had a lower specificity than responses to pertussis toxin, possibly because of cross-reactions with antigens of different origins. Responses to pertactin have had a lower sensitivity than those to the other 2 antigens. Wide use of serum IgG antipertussis toxin antibody levels as a diagnostic indicator, however, is limited. The decay of IgG anti-pertussis toxin antibody levels is more rapid than that of IgG levels in response to filamentous hemagglutinin, pertactin or fimbriae ${ }^{53,54}$ and the antibody response to pertussis toxin has been found to vary considerably, both in magnitude and in duration, between individuals..$^{55}$ Only a small subset of patients may have a humoral response of sufficient magnitude and duration for diagnosis. ${ }^{55}$ Nevertheless, a serum IgG anti-pertussis toxin antibody level above 100 $125 \mathrm{EU} / \mathrm{mL}$ has been considered a reasonable threshold for a positive test result. ${ }^{8}$ The variability of results, the usefulness of this method only late in the clinical course of the disease and the lack of standardized commercial test kits make serologic testing difficult to use in common practice with reproducible results. A combination of various methods should be used instead, matching culture or PCR results with serologic test results. ${ }^{8}$

\begin{tabular}{|c|c|c|c|c|c|c|c|}
\hline Study & $\begin{array}{l}\text { Location } \\
\text { of study }\end{array}$ & $\begin{array}{l}\text { Patient age } \\
\text { group }\end{array}$ & Vaccinated & $\begin{array}{l}\text { Duration of } \\
\text { cough, wk }\end{array}$ & $\begin{array}{l}\% \text { of cases with } \\
\text { spasmodic cough }\end{array}$ & $\begin{array}{c}\% \text { of cases } \\
\text { with vomiting }\end{array}$ & $\begin{array}{l}\% \text { of cases } \\
\text { with apnea }\end{array}$ \\
\hline \multirow[t]{2}{*}{ Tozzi et al, $2003^{11}$} & \multirow[t]{2}{*}{ Italy } & \multirow[t]{2}{*}{$6 \mathrm{mo}-6 \mathrm{yr}$} & No & $7-9 *$ & $83-98$ & $76-86 \dagger$ & $73-84 \dagger$ \\
\hline & & & Yes & $4-6^{*}$ & $65-91$ & $54-71 \dagger$ & $35-47 \dagger$ \\
\hline Preziosi et al, $2003^{12}$ & Senegal & $6 \mathrm{mo}-8 \mathrm{yr}$ & No & $14^{*}$ & NR & 74 & NR \\
\hline Senzilet et al, $2001^{2}$ & Canada & $\geq 12 \mathrm{yr}$ & No & $8 \ddagger$ & NR & 45 & 14 \\
\hline
\end{tabular}

Table 4: Sensitivity of diagnostic tests for pertussis in various studies involving adults*

\begin{tabular}{|c|c|c|c|c|c|}
\hline \multirow[b]{2}{*}{ Study } & \multirow{2}{*}{$\begin{array}{l}\text { Duration } \\
\text { of cough, } d\end{array}$} & \multicolumn{4}{|c|}{ Sensitivity, $\%$} \\
\hline & & Culture & PCR & & Serologic testing (antigens) \\
\hline Mink et al, $1992^{38}$ & $\geq 6$ & 0 & NA & 100 & (IgG/A-PT, IgG/A-FHA) \\
\hline $\begin{array}{l}\text { Rosenthal et al, } \\
1995^{39}\end{array}$ & $>6$ & 10 & NA & 100 & (IgG/A-PT, IgG/A-FHA) \\
\hline Gilberg et al, $2002^{40}$ & $>6$ & 1 & 51 & 57 & (IgG-PT) \\
\hline $\begin{array}{l}\text { Schmitt-Grohé et al, } \\
1995^{41}\end{array}$ & $\geq 7$ & 8 & 13 & 92 & $\begin{array}{l}\text { (IgG/A-PT, IgG/A-FHA, IgG/A-PRN, } \\
\text { IgG/A-FIM2, agglutinins) }\end{array}$ \\
\hline Senzilet et al, $2001^{2}$ & $>7$ & 2 & 3 & 95 & $\begin{array}{l}\text { (IgG/A-PT, IgG/A-FHA, IgG/A-PRN, } \\
\operatorname{lgG} / \mathrm{A}-\mathrm{FIM} 2)\end{array}$ \\
\hline Strebel et al, $2001^{42}$ & $>7$ & 30 & 37 & 89 & (IgG/A-PT) \\
\hline Wright et al, $1995^{43}$ & $\geq 14$ & 0 & NA & 100 & (IgG-PT, IgG-FHA) \\
\hline $\begin{array}{l}\text { Birkebaek et al, } \\
1999^{44}\end{array}$ & $>14$ & 11 & 32 & 97 & (IgG-PT) \\
\hline $\begin{array}{l}\text { Wirsing von Konig } \\
\text { et al, } 1995^{45}\end{array}$ & $>21$ & 1 & NA & 100 & (IgG/A-PT, IgG/A-FHA, IgG/A-PRN) \\
\hline
\end{tabular}

Note: $\mathrm{PCR}=$ polymerase chain reaction, $\mathrm{NA}=$ not available, $\lg \mathrm{G} / \mathrm{A}=\lg \mathrm{g}$ or $\lg \mathrm{A}, \mathrm{PT}=$ pertussis toxin, $\mathrm{FHA}=$ filamentous hemagglutinin $P R N=$ pertactin, $\mathrm{FIM}=$ fimbriae.

*Adapted from reference 8 . 


\section{Treatment}

Since a timely laboratory confirmation of pertussis diagnosis is problematic, administering an antibiotic on the basis of a clinical diagnosis should be considered. Antibiotics eradicate $B$. pertussis from the airway but limit the severity of disease only if started in the catarrhal phase (Table 1)..$^{56,57}$ The standard treatment of pertussis has been a full dose of erythromycin for 14 days. ${ }^{58}$ Evidence suggests that a shorter, 7 -day course is equally effective..$^{59}$ More recently many national agencies have tended to encourage the use of other macrolides for therapy. ${ }^{60} \mathrm{New}$ macrolides exhibit high and sustained intracellular penetration and therefore may be particularly effective against organisms such as B. pertussis, although they are more expensive than erythromycin. ${ }^{61}$ Azithromycin, $10 \mathrm{mg} / \mathrm{kg}$ on the first day followed by a daily dose of $5 \mathrm{mg} / \mathrm{kg}$ (maximum dose $1000 \mathrm{mg}$ on day 1 and 500 $\mathrm{mg}$ on days 2 to 5 ), has been shown to be effective in eradicating B. pertussis in $97 \%$ of cases after 2-3 days and in $100 \%$ after $14-21$ days. $^{62}$ In a study involving 37 patients aged 2-18 months who were given azithromycin for 3-5 days, $94 \%$ had negative cultures for pertussis 7 days after the initiation of therapy and $100 \%$ had negative cultures 14 days after the initiation of therapy. ${ }^{63}$ A comparison of erythromycin with azithromycin in a pediatric population showed that the drugs were equally effective in eradicating $B$. pertussis (100\% efficacy) 1 week after the end of treatment. ${ }^{57}$ Clarithromycin has been shown to be efficacious in treating patients with pertussis as well. ${ }^{64}$

Resistance to erythromycin seems exceptional, but sensitivity to this and other macrolides is rarely performed during laboratory diagnosis. ${ }^{65}$ In case of intolerance to macrolides or resistance, use of trimethoprim-sulfamethoxazole (8 and $40 \mathrm{mg} / \mathrm{kg}$ per day, respectively, in divided doses) is indicated..$^{58}$

The frequent gastrointestinal side effects observed in patients treated with erythromycin may reduce compliance. ${ }^{57}$
Moreover, the administration of erythromycin in infants may be associated with pyloric stenosis in up to $3.5 \%$ of cases. ${ }^{66}$ Gastrointestinal symptoms such as nausea, vomiting or diarrhea are observed in up to $41 \%$ of patients given erythromycin ${ }^{57}$ and in up to $19 \%$ of those given azithromycin..$^{57,62}$ Azithromycin has also been associated with a slight and transient elevation of liver enzyme levels in up to $20 \%$ of patients. ${ }^{63}$

Attention must be paid to potential drug interactions. Erythromycin can increase serum concentrations of theophylline, carbamazepine, warfarin, cyclosporine and terfenadine when administered concurrently. Clarithromycin interacts with theophylline, carbamazepine and terfenadine. The effect of these drugs administrated concurrently with azithromycin has not been studied. ${ }^{61}$

Use of dexbrompheniramine plus pseudoephedrine for 1 week, or ipratropium $(0.06 \%)$ nasal spray for 1 week, has been proposed for the treatment of cough. Alternatively, inhaled ipratropium therapy (four $18-\mu \mathrm{g}$ puffs 4 times daily using a metered-dose inhaler with spacer) for 1-3 weeks, systemic corticosteroid therapy tapered over $2-3$ weeks, or antitussives acting on the cough centre in the brain have been used. ${ }^{67}$ However, a recent systematic review that examined the efficacy of antihistamines, diphenhydramine, corticosteroids and salbutamol concluded that the effectiveness of these therapies in treating cough in pertussis is uncertain and that their use is not justified. ${ }^{68}$

Treatment of severe cases is mostly supportive. In some cases intravenous pertussis immune globulin therapy has been shown to decrease whooping, to improve oxygen saturation and to stop bradicardic episodes. ${ }^{69,70}$ Recently, leukopheresis and exchange transfusion have been proposed to reduce the leukocyte mass in cases with very high leukocyte counts. ${ }^{71}$ Extracorporeal membrane oxygenation is widely used in the management of severe pertussis, but it has had limited success, and pertussis severe enough to require its use is in itself a predictor of a poor outcome..$^{32,34}$

Table 5: Recommendations of the US Centers for Disease Control and Prevention for antibiotic prophylaxis in close contacts of patients with pertussis, regardless of vaccination status, to prevent health care-associated pneumonia ${ }^{72}$

\begin{tabular}{|c|c|c|c|c|}
\hline Drug & Dose & $\begin{array}{l}\text { Duration of } \\
\text { prophylaxis, } d\end{array}$ & Indication & Contraindications \\
\hline Erythromycin & $\begin{array}{l}\text { Children: } 40-50 \mathrm{mg} / \mathrm{kg} \text { daily } \\
\text { Aduls: } 500 \mathrm{mg} 4 \text { times daily if } \\
\text { erythromycin estolate; } 333 \mathrm{mg} 3 \\
\text { times daily if delayed-release tablets }\end{array}$ & 14 & First-choice therapy & $\begin{array}{l}\text { Intolerance to } \\
\text { macrolides; age } \leq 2 \mathrm{wk}\end{array}$ \\
\hline Azithromycin & $\begin{array}{l}10-12 \mathrm{mg} / \mathrm{kg} \text { daily } \\
10 \mathrm{mg} / \mathrm{kg} \text { on day } 1 ; 5 \mathrm{mg} / \mathrm{kg} \text { daily } \\
\text { on days } 2-5\end{array}$ & $\begin{array}{c}5-7 \\
5\end{array}$ & $\begin{array}{l}\text { Patients with intolerance to } \\
\text { erythromycin or infants aged } \leq 2 \text { wk }\end{array}$ & Intolerance to macrolides \\
\hline Clarithromycin & $\begin{array}{l}\text { Children: } 15-20 \mathrm{mg} / \mathrm{kg} \text { daily in } \\
\text { divided doses } \\
\text { Adults: } 500 \mathrm{mg} \text { twice daily }\end{array}$ & $10-14$ & $\begin{array}{l}\text { Patients with intolerance to } \\
\text { erythromycin or infants aged } \leq 2 \mathrm{wk}\end{array}$ & Intolerance to macrolides \\
\hline $\begin{array}{l}\text { Trimethoprim- } \\
\text { sulfamethoxazole } \\
\text { (TMP-SXT) }\end{array}$ & $\begin{array}{l}\text { Children: TMP } 8 \mathrm{mg} / \mathrm{kg} \text { and } \\
\text { SXT } 40 \mathrm{mg} / \mathrm{kg} \text { daily in divided doses } \\
\text { Adults: one double-strength tablet } \\
\text { twice daily }\end{array}$ & 14 & $\begin{array}{l}\text { Hypersensitivity or intolerance to } \\
\text { macrolides }\end{array}$ & $\begin{array}{l}\text { Pregnancy at term; } \\
\text { nursing; age }<2 \mathrm{mo}\end{array}$ \\
\hline
\end{tabular}




\section{Prevention of secondary cases}

Prevention of secondary cases is of upmost importance in health care settings and in households with infants. An accelerated schedule for vaccinating children less than 7 years old who have not completed their primary vaccinations is recommended, and the first dose of vaccine can be administered as early as 6 weeks of age. ${ }^{72}$ Close contacts should also receive antibiotic prophylaxis (Table 5). The US Centers for Disease Control and Prevention (CDC) still recommends erythromycin as the drug of choice in these cases except in infants 2 weeks of age or younger. The treatment should extend over 14 days for the prevention of health care-associated pneumonia. ${ }^{72}$ Patients intolerant to erythromycin or infants too young to be given the drug should be treated with azithromycin or clarithromycin. Those who do not tolerate macrolides should receive trimethoprim-sulfamethoxazole. ${ }^{72}$ Patients are considered not to be contagious after 5 days of antimicrobial treatment, or 21 days after the onset of cough if unable to take antibiotics.

Despite evidence that antibiotic prophylaxis has been successful in controlling outbreaks of pertussis, the effectiveness of erythromycin therapy in preventing individual secondary cases of pertussis has been considered modest. ${ }^{73,74}$ Erythromycin prophylaxis is more efficacious if initiated within 21 days (preferably 14 days) of onset of paroxysmal cough in the index case. ${ }^{74,75}$

\section{Conclusion}

Long after the discovery of effective antibiotic treatments and the implementation of universal vaccination strategies, pertussis remains a disease associated with an important burden even in developed countries. Since the clinical presentation of pertussis has changed because of vaccination, the disease likely is largely underdiagnosed. The development of sensitive and standardized diagnostic methods is essential. Treatment and prophylaxis with macrolides other than erythromycin will likely ensure better compliance.

\section{This article has been peer reviewed.}

From the Epidemiology Unit, Bambino Gesù Hospital (Tozzi), and the National Epidemiology Centre, Istituto Superiore di Sanità (Pastore Celentano, Ciofi degli Atti, Salmaso), Rome, Italy.

Competing interests: None declared.

Contributors: Alberto Tozzi designed the structure of the paper, performed the literature search and assembly of data, and drafted and revised the manuscript. All of the authors contributed equally to the preparation, analysis and synthesis of the available data and approved the final version to be published.

\section{References}

1. Pertussis vaccines. Wkly Epidemiol Rec 1999;74:137-44.

2. Senzilet LD, Halperin SA, Spika JS, Alagaratnam M, Morris A, Smith B; Sentinel Health Unit Surveillance System Pertussis Working Group. Pertussis is a frequent cause of prolonged cough illness in adults and adolescents. Clin Infect Dis 2001;32:1691-7.
3. Tanaka M, Vitek CR, Pascual FB, Bisgard KM, Tate JE, Murphy TV. Trends in pertussis among infants in the United States, 1980-1999. FAMA 2003;290:2968-75.

4. Skowronski DM, De Serres G, MacDonald D, Wu W, Shaw C, Macnabb J, et al. The changing age and seasonal profile of pertussis in Canada. 7 Infect Dis 2002;185:1448-53.

5. Ntezayabo B, De Serres G, Duval B. Pertussis resurgence in Canada largely caused by a cohort effect. Pediatr Infect Dis 7 2003;22:22-7.

6. Tozzi AE, Pastore Celentano L, Paramatti D, Lana S. EUVAC-NET pertussis surveillance. Final report. EUVAC.NET; 2004. Available: www.ssi.dk/euvac (click on "Pertussis report" at left; accessed 2005 Jan 13).

7. Miller E, Gay NJ. Epidemiological determinants of pertussis. Dev Biol Stand 1997;89:15-23.

8. Wirsing von Konig CH, Halperin S, Riffelmann M, Guiso N. Pertussis of adults and infants. Lancet Infect Dis 2002;2:744-50.

9. Kerr JR, Matthews RC. Bordetella pertussis infection: pathogenesis, diagnosis, management, and the role of protective immunity. Eur 7 Clin Microbiol Infect Dis 2000;19:77-88.

10. Locht C. Molecular aspects of Bordetella pertussis pathogenesis. Int Microbiol 1999;2:137-44.

11. Tozzi AE, Ravà L, Ciofi degli Atti ML, Salmaso S; Progetto Pertosse Working Group. Clinical presentation of pertussis in unvaccinated and vaccinated children in the first six years of age. Pediatrics 2003;112:1069-75.

12. Preziosi MP, Halloran ME. Effects of pertussis vaccination on disease: vaccine efficacy in reducing clinical severity. Clin Infect Dis 2003;37:772-9.

13. Wang J, Yang Y, Li J, Mertsola J, Arvilommi H, Shen X, et al. Infantile pertussis rediscovered in China. Emerg Infect Dis 2002;8:859-60.

14. Hoppe JE. Neonatal pertussis. Pediatr Infect Dis 7 2000;19:244-7.

15. De Serres G, Shadmani R, Duval B, Boulianne N, Dery P, Douville Fradet $\mathrm{M}$, et al. Morbidity of pertussis in adolescents and adults. 7 Infect Dis 2000; 182:174-9.

16. Yaari E, Yafe-Zimernam Y, Schwartz SB, Slater PE, Shvartzman P, Andoren $\mathrm{N}$, et al. Clinical manifestations of Bordetella pertussis infection in immunized children and young adults. Chest 1999;115:1254-8.

17. Heininger U, Klich K, Stehr K, Cherry JD. Clinical findings in Bordetella pertussis infections: results of a prospective multicenter surveillance study. Pediatrics 1997;100(6):E10.

18. Ivanoff B, Robertson SE. Pertussis: a worldwide problem. Dev Biol Stand 1997;89:3-13.

19. Pertussis — United States, 1997-2000. MMWR Morb Mortal Wkly Rep 2002; 51(4):73-6

20. Farizo KM, Cochi SL, Zell ER, Brink EW, Wassilak SG, Patriarca PA. Epidemiological features of pertussis in the United States, 1980-1989. Clin Infect Dis 1992;14:708-19.

21. Halperin SA, Wang EE, Law B, Mills E, Morris R, Dery P, et al. Epidemiological features of pertussis in hospitalized patients in Canada, 1991-1997: report of the Immunization Monitoring Program-Active (IMPACT). Clin Infect Dis 1999;28:1238-43.

22. Stojanov S, Liese J, Belohradsky BH. Hospitalization and complications in children under 2 years of age with Bordetella pertussis infection. Infection 2000;28:106-10.

23. Pelosi JW, Schulte JM. Use of birth certificates and surveillance data to characterize reported pertussis among Texas infants and young children, 1995 to 2000. South Med F 2003;96:1231-7.

24. Pertussis - United States, January 1992-June 1995. MMWR Morb Mortal Wkly Rep 1995;44:525-9.

25. Miller CL, Fletcher WB. Severity of notified whooping cough. BMF 1995; $117-9$.

26. Herzig P, Hartmann C, Fischer D, Weil J, von Kries R, Giani G, et al. Pertussis complications in Germany: 3 years of hospital-based surveillance during the introduction of the acellular vaccine. Infection 1998;26:227-31.

27. Gil A, Oyaguez I, Carrasco P, Gonzalez A. Hospital admissions for pertussis in Spain, 1995-1998. Vaccine 2001;19:4791-4.

28. Elliott E, McIntyre P, Ridley G, Morris A, Massie J, McEniery J, et al. National study of infants hospitalized with pertussis in the acellular vaccine era Pediatr Infect Dis 7 2004;23:246-52.

29. Juretzko P, Fabian-Marx T, Haastert B, Giani G, von Kries R, Wirsing von Konig CH. Pertussis in Germany: regional differences in management and vaccination status of hospitalized cases. Epidemiol Infect 2001;127:63-71.

30. De Melker HE, Schellekens JF, Neppelenbroek SE, Mooi FR, Rumke HC, Conyn-van Spaendonck MA. Reemergence of pertussis in the highly vaccinated population of the Netherlands: observations on surveillance data. Emerg Infect Dis 2000;6:348-57.

31. Wortis N, Strebel PM, Wharton M, Bardenheier B, Hardy IRB. Pertussis deaths: report of 23 cases in the United States, 1992-1993. Pediatrics 1996;97: 607-12.

32. Mikelova LK, Halperin SA, Scheifele D, Smith B, Ford-Jones E, Vaudry W, et al. Predictors of death in infants hospitalized with pertussis: a case-control study of 16 pertussis deaths in Canada. 7 Pediatr 2003;143:576-81.

33. Pierce C, Klein N, Peters M. Is leukocytosis a predictor of mortality in severe pertussis infection? Intensive Care Med 2000;26:1512-4. 
34. Pooboni S, Roberts N, Westrope C, Jenkins DR, Killer H, Pandya HC, et al. Extracorporeal life support in pertussis. Pediatr Pulmonol 2003;36:310-5.

35. Williams GD, Numa A, Sokol J, Tobias V, Duffy BJ. ECLS in pertussis: Does it have a role? Intensive Care Med 1998;24:1089-92.

36. Heininger U, Kleemann WJ, Cherry JD; Sudden Infant Death Syndrome Study Group. A controlled study of the relationship between Bordetella pertussis infections and sudden unexpected deaths among German infants. Pediatrics 2004;114:e9-e15.

37. Fung KSC, Yeung WL, Wong TW, So KW, Cheng AFB. Pertussis: A reemerging infection? f Infection 2004;48:145-8.

38. Mink CM, Cherry JD, Christenson P, Lewis K, Pineda E, Shlian D, et al. A search for Bordetella pertussis infection in university students. Clin Infect Di. 1992;14:464-71.

39. Rosenthal S, Strebel P, Cassiday P, Sanden G, Brusuelas K, Wharton M. Pertussis infection among adults during the 1993 outbreak in Chicago. 7 Infect Dis $1995 ; 171: 1650-2$

40. Gilberg S, Njamkepo E, Du Chatelet IP, Partouche H, Gueirard P, Ghasarossian C, et al. Evidence of Bordetella pertussis infection in adults presenting with persistent cough in a French area with very high whole-cell vaccine coverage. 7 Infect Dis 2002;186:415-8.

41. Schmitt-Grohé S, Cherry JD, Heininger U, Uberall MA, Pineda E, Stehr K. Pertussis in German adults. Clin Infect Dis 1995;21:860-6.

42. Strebel P, Nordin J, Edwards K, Hunt J, Besser J, Burns S, et al. Populationbased incidence of pertussis among adolescents and adults, Minnesota, 19951996. 7 Infect Dis 2001;183:1353-9.

43. Wright SW, Edwards KM, Decker MD, Zeldin MH. Pertussis infections in adults with persistent cough. 7AMA 1995;273:1044-6.

44. Birkebaek NH, Kristiansen M, Seefeldt T, Degn J, Moller A, Heron I, et al Bordetella pertussis and chronic cough in adults. Clin Infect Dis 1999;29:1239-42.

45. Wirsing von Konig CH, Postels-Multani S, Bock HL, Schmitt HJ. Pertussis in adults: frequency of transmission after household exposure. Lancet 1995 ; 346:1326-9.

46. Greco D, Salmaso S, Mastrantonio P, Giuliano M, Tozzi AE, Anemona A, et al. A controlled trial of two acellular vaccines and one whole-cell vaccine against pertussis. N Engl f Med 1996;334:341-8.

47. Gustafsson L, Hollander HO, Olin P, Reizenstein E, Storsaeter J. A controlled trial of a two-component acellular, a five-component acellular, and a whole-cell pertussis vaccine. N Engl 7 Med 1996;334:349-55.

48. Trollfors B, Taranger J, Lagergard T, Lind L, Sundh V, Zackrisson G, et al. A placebo-controlled trial of a pertussis-toxoid vaccine. $N$ Engl $\mathcal{F} \mathrm{Med}$ 1995;333:1045-50.

49. Lievano FA, Reynolds MA, Waring AL, Ackelsberg J, Bisgard KM, Sanden $\mathrm{GN}$, et al. Issues associated with and recommendations for using PCR to detect outbreaks of pertussis. 7 Clin Microbiol 2002;40:2801-5.

50. Qin X, Turgeon DK, Ingersoll BP, Monsaas PW, Lemoine CI, Tsosie T, et al. Bordetella pertussis PCR: simultaneous targeting of signature sequences. $\mathrm{Di}$ agn Microbiol Infect Dis 2002;43:269-75.

51. Lingappa JR, Lawrence W, West-Keefe S, Gautom R, Cookson BT. Diagnosis of community-acquired pertussis infection: comparison of both culture and fluorescent-antibody assays with PCR detection using electrophoresis or dot blot hybridization. 7 Clin Microbiol 2002;40:2908-12.

52. Cherry JD, Xing DX, Newland P, Patel K, Heininger U, Corbel MJ. Determination of serum antibody to Bordetella pertussis adenylate cyclase toxin in vaccinated and unvaccinated children and in children and adults with pertussis. Clin Infect Dis 2004;38:502-7.

53. Trollfors B, Lagergard T, Gunnarsson E, Taranger J. Determination of pertactin IgG antibodies for the diagnosis of pertussis. Clin Microbiol Infect 2003;9:585-9.

54. Heininger U, Cherry JD, Stehr K. Serologic response and antibody-titer decay in adults with pertussis. Clin Infect Dis 2004:38:591-4.

55. Teunis PF, van der Heijden OG, de Melker HE, Schellekens JF, Versteegh FG, Kretzschmar ME. Kinetics of the IgG antibody response to pertussis toxin after infection with $B$. pertussis. Epidemiol Infect 2002;129:479-89.

56. Bass JW. Erythromycin for treatment and prevention of pertussis. Pediatr Infect Dis 7 1986;5:154-7.

57. Langley JM, Halperin SA, Boucher FD, Smith B; Pediatric Investigators Collaborative Network on Infections in Canada (PICNIC). Azithromycin is as effective as and better tolerated than erythromycin estolate for the treatment of pertussis. Pediatrics 2004;114:e96-e101.

58. American Academy of Pediatrics. Pertussis. In Pickering LK, editor. Red book 2003. Report of the Committee on Infectious Diseases. 26th ed. Elk Grove Village (IL): The Academy; 2003. p. 472-86.

59. Halperin SA, Bortolussi R, Langley JM, Miller B, Eastwood BJ. Seven days of erythromycin estolate is as effective as fourteen days for the treatment of $\mathrm{Bor}$ detella pertussis infections. Pediatrics 1997;100:65-71.

60. National consensus conference on pertussis, Toronto, May 25-28, 2002. Can Commun Dis Rep 2003;29(Suppl 3):1-33.

61. Klein J. Clarithromycin and azithromycin. Pediatr Infect Dis f 1998;17:516-7.

62. Pichichero ME, Hoeger WJ, Casey JR. Azithromicin for the treatment of pertussis. Pediatr Infect Dis 7 2003;22:847-9.
63. Bace A, Zrnic T, Begovac J, Kuzmanovic N, Culig J. Short-term treatment of pertussis with azithromycin in infants and young children. Eur 7 Clin Microbiol Infect Dis 1999;18:296-8.

64. Lebel MH, Mehra S. Efficacy and safety of clarithromycin versus erythromycin for the treatment of pertussis: a prospective, randomized, single blind trial. Pediatr Infect Dis 7 2001;20:1149-54.

65. Wilson KE, Cassiday PK, Popovic T, Sanden GN. Bordetella pertussis isolates with a heterogeneous phenotype for erythromycin resistance. 7 Clin Microbiol 2002;40:2942-44.

66. Honein MA, Paulozzi LJ, Himelright IM, Lee B, Cragan JD, Patterson L, et al. Infantile hypertrophic pyloric stenosis after pertussis prophylaxis with erythromycin: a case review and cohort study. Lancet 1999;354:2101-5.

67. Irwin RS, Madison JM. The diagnosis and treatment of cough. $N$ Engl 7 Med 2000;343:1715-21.

68. Pillay V, Swingler G. Symptomatic treatment of the cough in whooping cough [Cochrane review]. In: Cochrane Library, Issue 2, 2004.

69. Granstrom M, Olinder-Nielsen AM, Holmblad P, Mark A, Hanngren K. Specific immunoglobulin for treatment of whooping cough. Lancet 1991;38:1230-3.

70. Bruss JB, Malley R, Halperin S, Dobson S, Dhalla M, McIver J, et al. Treatment of severe pertussis: a study of the safety and pharmacology of intravenous pertussis immunoglobulin. Pediatr Infect Dis 7 1999;18:505-11.

71. Romano MJ, Weber MD, Weisse ME, Siu BL. Pertussis pneumonia, hypoxemia, hyperleukocytosis, and pulmonary hypertension: improvement in oxygenation after a double volume exchange transfusion. Pediatrics 2004;114: e264-e266.

72. Tablan OC, Anderson LJ, Besser R, Bridges C, Hajjeh R; CDC; Healthcare Infection Control Practices Advisory Committee. Guidelines for preventing health-care-associated pneumonia, 2003: recommendations of CDC and the Healthcare Infection Control Practices Advisory Committee. MMWR Recomm Rep 2004;53(RR-3):1-36.

73. Wheeler JG, Tran TC, North P, Beavers-May T, Schutze GE, Snow SL. Barriers to public health management of a pertussis outbreak in Arkansas. Arch Pediatr Adolesc Med 2004;158:146-52.

74. Dodhia H, Miller E. Review of the evidence for the use of erythromycin in the management of persons exposed to pertussis. Epidemiol Infect 1998;120:143-9.

75. Dodhia H, Crowcroft NS, Bramley JC, Miller E. UK guidelines for use of erythromycin chemoprophylaxis in persons exposed to pertussis. 7 Public Health Med 2002;24:200-6.

Correspondence to: Dr. Alberto E. Tozzi, Epidemiology Unit, Bambino Gesù Hospital, Piazza S. Onofrio, 4, 00165 Rome, Italy; fax 39 06-68592583; alberto.tozzi@opbg.net

\section{Appendix 1: Search strategy}

We searched MEDLINE for relevant articles published from 1995 to 2004 using the following strategy:

- "whooping cough" [MeSH] + "epidemiology" [MeSH] + "human" [MeSH]

- "whooping cough" $[\mathrm{MeSH}]+$ "etiology" $[\mathrm{MeSH}]+$ "human" [MeSH]

- "whooping cough" [MeSH] + "signs and symptoms" [MeSH]+ "human" [MeSH]

- "whooping cough" $[\mathrm{MeSH}]+$ "laboratory techniques and procedures" [MeSH] + "human" [MeSH]

- "whooping cough" $[\mathrm{MeSH}]+$ "therapy" $[\mathrm{MeSH}]+$ "human" $[\mathrm{MeSH}]$

We also searched the Cochrane Library database using the term "whooping cough"

We found a total of 575 articles in the MEDLINE search and 3 in the Cochrane Library search. Articles without an available abstract were not considered. After reading the abstracts, we excluded articles that dealt with pertussis immunization only.

A total of 153 articles were thoroughly reviewed. Relevant references cited in these articles were retrieved and reviewed, even if they were published outside of the time frame of the main search. 